\title{
Effect of Chocolate Coating and Essential Oil Incorporation on the Sensory Acceptability of Protein Bars
}

\author{
Aishwarya Ayatti $^{1 *}$, Neena Joshi ${ }^{1}$, K. V. Jamuna ${ }^{1}$ and K. B. Suresha ${ }^{2}$ \\ ${ }^{1}$ Department of Food Science and Nutrition, \\ ${ }^{2}$ Department of AICRP- Post Harvest Technology, UAS, GKVK, Bengaluru-560065, \\ Karnataka, India \\ *Corresponding author
}

Keywords

Protein bar, sensory acceptability, coating, essential oil

Article Info

\section{Accepted:}

15 June 2021

Available Online:

10 July 2021
In the present investigation locally available ingredients were utilized to develop an acceptable protein bar from indigenous, and protein dense ingredients such as soya protein isolates, maize, skimmed milk powder, groundnut, watermelon seeds, cashew nut, almonds, cranberry, raisins along with other bar materials such as jaggery, ghee, sunflower oil, glycerol and gum acacia with a focus on meeting the basic criteria of protein bars. The standardized bars were coated with milk and dark chocolate with an objective to enhance visual appearance and increase consumer appeal and analyzed for their sensory acceptability. Essential oils were later incorporated into both chocolate coating at different levels to improve bar stability and acceptability. Coating of standardized protein bars improved the sensory acceptability of the products when compared with uncoated protein bars The incorporation of essential oils in coating material further improved the sensory scores of protein bars particularly in case of milk chocolate+ fennel essential oil and dark chocolate+ cinnamon essential oil protein bar samples. Hence in the present study both the coating material and essential oil incorporation has demonstrated positive significant role in sensory qualities of the developed protein bars.

\section{Introduction}

Protein bars are nutrition bars that contain a high proportion of protein to carbohydrates/fats, where the bar delivers at least 20 per cent of the recommended daily requirements of sedentary workers in protein per $100 \mathrm{~g}$ for claiming/labeling as high- protein/protein rich product under the Food Safety and Standards Amendment Regulations (Advertising and Claims) (FSSAI, 2019). Protein bars have particular marketing target, primarily consumed as a meal replacement in sports, athletic supplements, body building aids, and dieting because protein consumption leads to lower overall food intake, decreased 
total body weight, increased energy levels, improved muscle mass, and enhanced postexercise recovery (Artaza-Artabe et al., 2016). However, protein bars can be used in the segment of quick snacks (designed to temporarily satisfy hunger) or for nutrition of elderly and sick people. Individuals facing nutritional problems or irregular meals due to hectic work schedules and sedentary lifestyles can utilize these bars as healthier options for nourishment (Malecki et al., 2020), furthermore the meal replacement protein bars offer more balanced nutrition than snack or candy bars and provide satiety between meals (Lu and Zhou, 2019). Therefore, protein bars act as a quality source of nutrients and a convenient meal substitute (Padmashree et al., 2013) and are increasingly being perceived as a healthier option by the mainstream consumers and not just by bodybuilders or athletes (Bhaludra, 2019).

Commercially many nutritional bars are enrobed in chocolate and or chocolate flavored coatings or contain soft centers, such as caramel or cream, to improve taste. Chocolate coatings are semisolid suspensions of fine particles from sugar, cocoa and nonfat milk solids in an oily continuous phase. Cocoa butter is an important ingredient as it yields the main properties (gloss, texture and mouth feel) of chocolate which is solid at room temperature and upon ingestion undergo dissolution and melt on the tongue surface influencing characteristic mouth feel and release of flavour due to its sharp melting range just below body temperature(Glicerina et al., 2016). Thus, Chocolate coating with distinctive physical properties helps to improve visual appearance while at the same time enhancing consumer appeal and increasing market appeal of products when employed as confectionary coating for snacks and baked goods (Costa et al., 2015). Essential (volatile) plant oils are edible, medicinal and herbal secondary metabolites of plants that are generally recognized as safe (GRAS) by the FDA and can be used as a possible replacement for synthetic additives ( $\mathrm{Ju}$ et al., 2018). Generally, essential oils have phenolic groups responsible for their antioxidant activity and show most effectiveness against microbes (Abd-Elsalam and Khokhlov, 2015). The application of essential oils for shelf-life extension in foods is mainly due to their antioxidant and antimicrobial properties (Fernandez-Lopes and Viuda-Martos, 2018). The present study was carried out with an objective to incorporate essential oils in chocolate coating of protein bars and evaluate them for sensory acceptance.

\section{Materials and Methods}

The present investigation was carried out in the department of Food Science and Nutrition, University of Agricultural Sciences (UAS), GKVK, Bangalore. A detailed procedure of preparation of protein bars, chocolate coating and essential oils incorporation in chocolate coating of protein bars and their sensory quality assessments is described below.

\section{Procurement of raw materials}

All the ingredients used in protein bar preparation namely popped corn kernels, jaggery, honey, sunflower oil, groundnuts, cashew nuts, almonds, watermelon seeds, cranberries and black raisins were procured in a single lot from local market and stored in refrigerator. Soy protein isolate, skimmed milk powder, corn syrup, glycerol, gum acacia were obtained from Sridurga Sales Corporation, Peenya, Bengaluru. Cassia cinnamon and aniseed were procured from local market Bengaluru.

\section{Preparation of protein bar}

The protein bars based were prepared according to an indigenous method used for 
the preparation of peanut candy with minor modification as depicted in Figure 1 (Pallavi et al., 2014). Popped corns are prepared by heating the raw pop corn kernels with little oil in a sauce pan at medium high heat and cooking by covering the pan until all the kernels are popped. Pop corns and roasted nuts (groundnuts, cashew nuts, almonds, and watermelon seeds) were ground to coarse powder. All the ingredients namely ground popped corns, roasted nuts; soy protein isolate and skim milk powder, cranberries, black raisins and glycerol were dry mixed in a steel vessel. In a non-stick pan previously weighed jaggery, gum acacia and sunflower oil was heated to a temperature of $105-110^{\circ} \mathrm{C}$ to prepare the binder solution. The mixture was concentrated to get thick consistent syrup with 85 brix (soft ball stage) (Padmashree et al., 2012). To the hot binder syrup the above dry ingredients mixture was added and thoroughly mixed. Later the mass was transferred into the rectangular stainless steel mould with dimension of $22.5 \mathrm{~cm} \times 24 \mathrm{~cm} \times 2 \mathrm{~cm}$ and pressed firmly into the mould with a steel plate which enabled exertion of equal pressure on the bars. After pressing, it was cut in smaller bars of size $10 \mathrm{~cm} \times 3 \mathrm{~cm} \times 2 \mathrm{~cm}$ using bar cutter.

\section{Chocolate coating process}

The coating was applied to developed protein bars by using two kinds of chocolates i.e. milk and dark chocolate. The chocolate slabs were cut into small pieces and melted in a double boiler and then dipped in chocolate mixture for 20-30 seconds. Coated bars were drained for 10 seconds to remove the excess chocolate (Kimberlee, 2007).

\section{Extraction of essential oils}

The essential oils from fennel and cassia cinnamon were used in the study. The oils were extracted by hydro-distillation method using a clevenger apparatus (Fig 2). Three hundred grams of cleaned and dried extraction material was coarsely ground using pestle and mortar and hydro distilled in a round bottom flask fitted with condenser for $3-5 \mathrm{hr}$ at atmospheric pressure and constant temperature until no further oil was obtained. The highly aromatic oil was isolated from the water layer. After extraction, the essential oil was dehydrated over anhydrous sodium sulphate to remove excess water (Adinew, 2014).

\section{Incorporation of essential oils in coating material}

Essential oils were incorporated into both milk and dark chocolate coating material at five different concentrations namely $12.5 \mu \mathrm{l}, 25 \mu \mathrm{l}$, $50 \mu \mathrm{l}, 100 \mu \mathrm{l}$ and $200 \mu$ per $100 \mathrm{~g}$ of chocolate during the process of coating the bars.

\section{Sensory analysis}

The developed product was evaluated by a semi trained panel members for attributes of appearance, texture, color and over-all acceptability on a 9- point hedonic scale score card where score 9 was for liked extremely and 1 for extremely disliked samples.

\section{Total mean sensory score (MSS)}

It is the sum of scores of all the sensory attributes (appearance, colour, texture, flavour, taste and overall acceptability).

\section{Acceptability index (AI)}

Calculated using the following formula (Aparecida et al., 2016).

AI \%

Average score obtained for the product

Highest score given to
the product $\times 100$ 


\section{Statistical analysis}

Sensory results were subjected to one way analysis of variance (ANOVA) at $(\mathrm{p} \leq 0.05)$ significance levels using Duncan's multiple range tests and statistical analysis was carried out by using the software SPSS 16.0 (2007).

\section{Results and Discussion}

The results of effect of different coating material on the sensory acceptability of protein bars are given in Table 2 .

The mean sensory scores for all the sensory parameters for uncoated and milk and dark chocolate coated protein bars differed significantly. The mean sensory values for appearance and colour of milk chocolate coated protein bars had higher scores followed by dark chocolate coated and uncoated protein bars. Same trend was observed in the total mean sensory values for texture, flavor, taste and overall acceptability scores where milk chocolate coated protein bars obtained higher scores followed by dark chocolate coated and non-coated protein bars. From the sensory analysis results it was revealed that coated protein bars were more liked by the panellists when compared to non- coated protein bars. Among the coating material milk chocolate was more acceptable as revealed by sensory evaluation. According to Małecki et al., (2020) chocolate coating of high protein bars increased sensory scores of the tested products, masking specific smells, colour to a large extent and the aftertaste of some types of proteins, thus contributing to an increase in the overall sensory assessment.

\section{Cinnamon essential oil incorporation in dark chocolate}

The results of effect of cinnamon essential oil incorporation in dark chocolate coating of protein bars on the sensory acceptability are given in Figure 3. The mean sensory scores for all the sensory parameters for control and cinnamon essential oil incorporated protein bars at different concentrations showed significant results for flavour, taste and overall acceptability parameters, whereas appearance, colour and texture values did not vary among the different products. The mean sensory values for flavour, taste and overall acceptability parameters of all the protein bars obtained similar scores, where values tended to decrease with increase in the concentration of essential oils. The protein bars incorporated with highest concentration of essential oil $(200 \mu \mathrm{l})$ obtained least scores, followed by protein bars incorporated with moderate concentration of essential oil $(100 \mu \mathrm{l})$ which obtained moderate scores and the protein bars incorporated with lower concentrations of essential oil $(50 \mu \mathrm{l})$ obtained slightly higher scores and the protein bars incorporated with lowest concentration of essential oil (12.5 and $25 \mu \mathrm{l})$ scored highest which were on par with control samples values for flavor, taste and overall acceptability respectively.

From the sensory analysis results it was revealed that the acceptability of dark chocolate coated protein bars was significantly affected by the incorporation of cinnamon essential oil at concentrations of $50 \mu 1$ and above, whereas lower concentrations of cinnamon essential oil was liked by the panellists and the sensory scores were on par with control.

Dwijatmoko et al., (2016) studied the effect of cinnamon essential oils addition on the sensory attributes of dark chocolate and reported that addition of 0.25 per cent cinnamon essential oils obtained the highest score from the panellists on the taste parameter among the samples while adding 0.50 per cent and 0.75 per cent resulted in too much spicy taste, which decreased the acceptability 
Cinnamon essential oil incorporation in milk chocolate

The results of effect of cinnamon essential oil incorporation in milk chocolate coating of protein bars on the sensory acceptability are given in Figure 4.

The mean sensory scores for all the sensory parameters for control and cinnamon essential oil incorporated protein bars at different concentrations showed significant results for flavor, taste and overall acceptability parameters, whereas appearance, colour and texture values did not vary among the different products. The mean sensory values for flavor, taste and overall acceptability parameters of all the protein bars obtained similar scores, where values tended to decrease with increase in the concentration of essential oils. The protein bars incorporated with highest concentration of essential oil (200 $\mu 1)$ obtained least scores, followed by protein bars incorporated with moderate concentration of essential oil $(100 \mu \mathrm{l})$ which obtained marginal scores and the protein bars incorporated with lower concentrations of essential oil $(50 \mu \mathrm{l})$ obtained slightly higher scores and the protein bars incorporated with lowest concentration of essential oil (12.5 and $25 \mu \mathrm{l})$ scored highest which were on par with control samples values for flavor, taste and overall acceptability respectively.

From the sensory analysis results it was revealed that the acceptability of milk chocolate coated protein bars was significantly affected by the incorporation of cinnamon essential oil at concentrations of $50 \mu 1$ and above, whereas lower concentrations of cinnamon essential oil was liked by the panellists and the sensory scores were on par with control. Ilmi et al., (2017) reported that milk chocolate bar with 0.1 per cent addition of cinnamon essential oil was most preferred by panellists with highest level of overall acceptance than 0.3 and 0.5 percentage addition. Essential oil has a bitter taste, sometimes sharp, biting, gives the impression of warmth depending on the type of their components (Inna et al., 2010). Therefore, panellists acceptance was decreased with increasing concentration of cinnamon essential oil.

\section{Fennel essential oil incorporation in dark chocolate}

The results of effect of fennel essential oil incorporation in dark chocolate coating of protein bars on the sensory acceptability are given in Figure 5.

The mean sensory scores for all the sensory parameters for control and fennel essential oil incorporated protein bars at different concentrations were non-significant except for taste. The mean sensory values for taste showed highest scores at $50 \mu \mathrm{l}$ of essential oil incorporation which is also on par with the control protein bar samples. Moderate taste scores were obtained at higher essential oil incorporation $(100 \mu 1$ and $200 \mu 1)$ and at 12.5 $\mu \mathrm{l}$ concentration and $25 \mu \mathrm{l}$ essential oil level obtained the least scores for taste parameter.

From the sensory analysis results it was revealed that the higher concentrations of fennel essential oil in dark chocolate coating of protein bar samples was liked by the panellists and the sensory scores were on par with control (without essential oil). 
Fig.1 Formulation procedure for protein bars

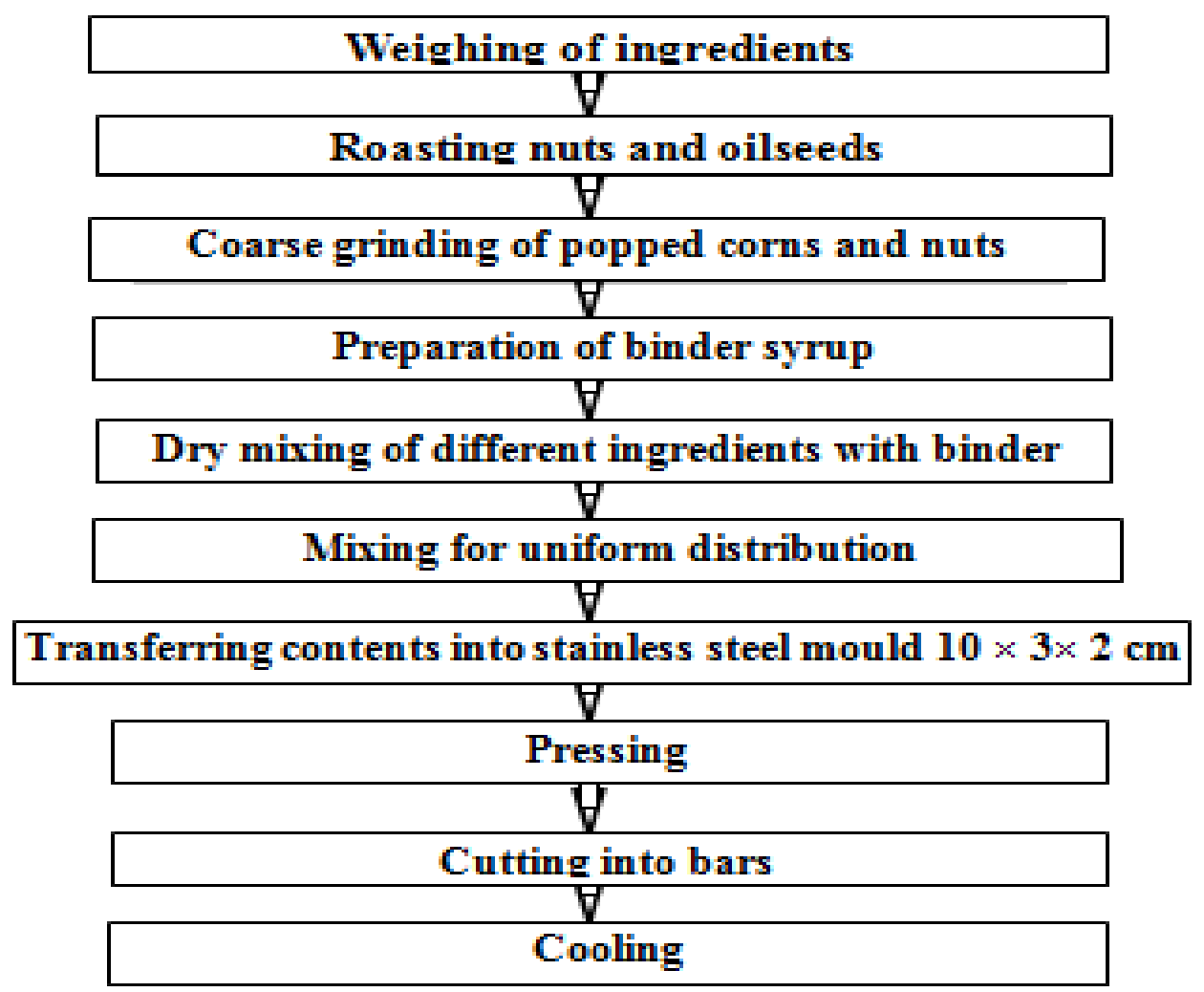

Table.1 Quantity (g/100g) of ingredients used for the preparation of protein bars

\begin{tabular}{|c|c|}
\hline Ingredients & Quantity (g/100g) \\
\hline Popped corn & 5 \\
\hline Soy protein isolate & 18 \\
\hline Skim milk powder & 6 \\
\hline Jaggery & 44 \\
\hline Sunflower oil & 4 \\
\hline Ghee & 4 \\
\hline Glycerol & 11 \\
\hline Gum & 2 \\
\hline Groundnuts & 1 \\
\hline Watermelon seeds & 1 \\
\hline Cashew nuts & 1 \\
\hline Almonds & 1 \\
\hline Black raisins & 1 \\
\hline Cranberries & 1 \\
\hline Total & 100 \\
\hline
\end{tabular}


Table.2 Sensory scores of chocolate coated protein bars

\begin{tabular}{|c|c|c|c|c|c|c|c|c|}
\hline $\begin{array}{c}\text { Protein bar } \\
\text { samples }\end{array}$ & Appearance & Colour & Texture & Flavor & Taste & $\begin{array}{c}\text { Overall } \\
\text { acceptability }\end{array}$ & $\begin{array}{c}\text { Total } \\
\text { mean } \\
\text { score }\end{array}$ & $\begin{array}{c}\text { Acceptabilit } \\
\mathbf{y} \text { index }(\%)\end{array}$ \\
\hline Uncoated bars & $8.00 \pm 14^{\mathrm{a}}$ & $8.11 \pm 0.38^{\mathrm{a}}$ & $7.71 \pm 0.54^{\mathrm{a}}$ & $7.94 \pm 0.54^{\mathrm{a}}$ & $8.01 \pm 0.46^{\mathrm{a}}$ & $8.07 \pm 0.40^{\mathrm{a}}$ & 48.21 & 89.28 \\
\hline $\begin{array}{c}\text { Milk chocolate } \\
\text { coated bars }\end{array}$ & $8.63 \pm 0.28^{\mathrm{c}}$ & $8.73 \pm 0.25^{\mathrm{b}}$ & $8.52 \pm 0.39^{\mathrm{b}}$ & $8.48 \pm 0.43^{\mathrm{b}}$ & $8.49 \pm 0.44^{\mathrm{b}}$ & $8.59 \pm 0.34^{\mathrm{b}}$ & 51.44 & 95.26 \\
\hline $\begin{array}{c}\text { Dark chocolate } \\
\text { coated bars }\end{array}$ & $8.30 \pm 0.59^{\mathrm{b}}$ & $8.36 \pm 0.48^{\mathrm{a}}$ & $8.29 \pm 0.62^{\mathrm{b}}$ & $8.31 \pm 0.66^{\mathrm{b}}$ & $8.18 \pm 0.36^{\mathrm{b}}$ & $8.49 \pm 0.51^{\mathrm{b}}$ & 49.63 \\
\hline F-Value & $*$ & $*$ & $*$ & $*$ & $*$ & $*$ & \\
\hline S.Em. \pm & 0.12 & 0.12 & 0.17 & 0.17 & 0.13 & 0.14 & \\
\hline C.D & 0.23 & 0.23 & 0.34 & 0.34 & 0.26 & 0.27 & \\
\hline
\end{tabular}

Values expressed as Mean \pm SD.

* Significant $(\mathrm{P}<0.05)$.

Values with different superscripts within same column differ significantly.

Fig.2 Hydro distillation of essential oil in clevenger apparatus

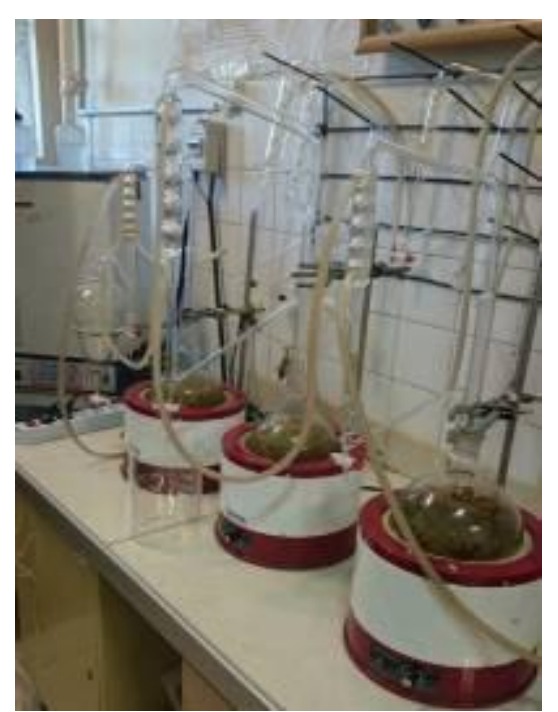


Fig.3 Effect on sensory scores of cinnamon essential oil (CEO) incorporation in protein bars coated with dark chocolate

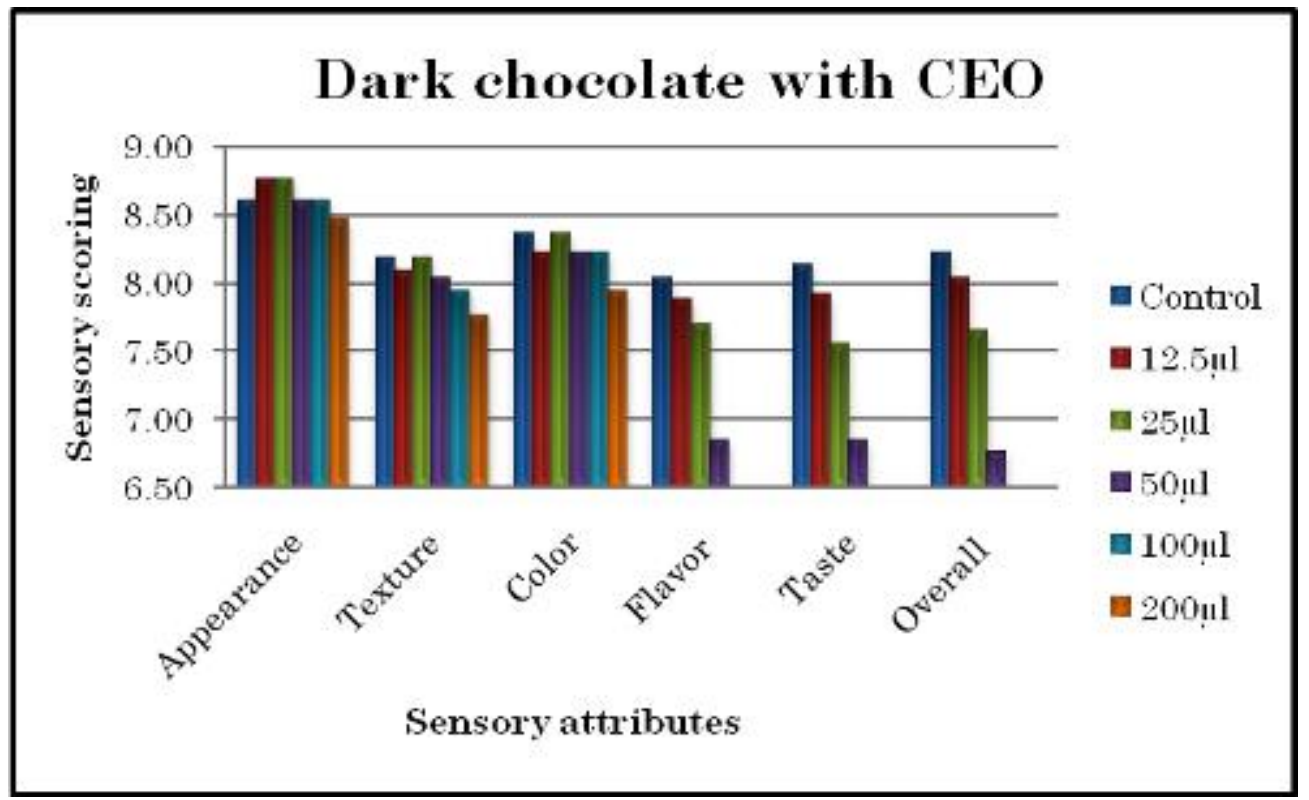

Fig.4 Effect on sensory scores of cinnamon essential oil (CEO) incorporation in protein bars coated with milk chocolate

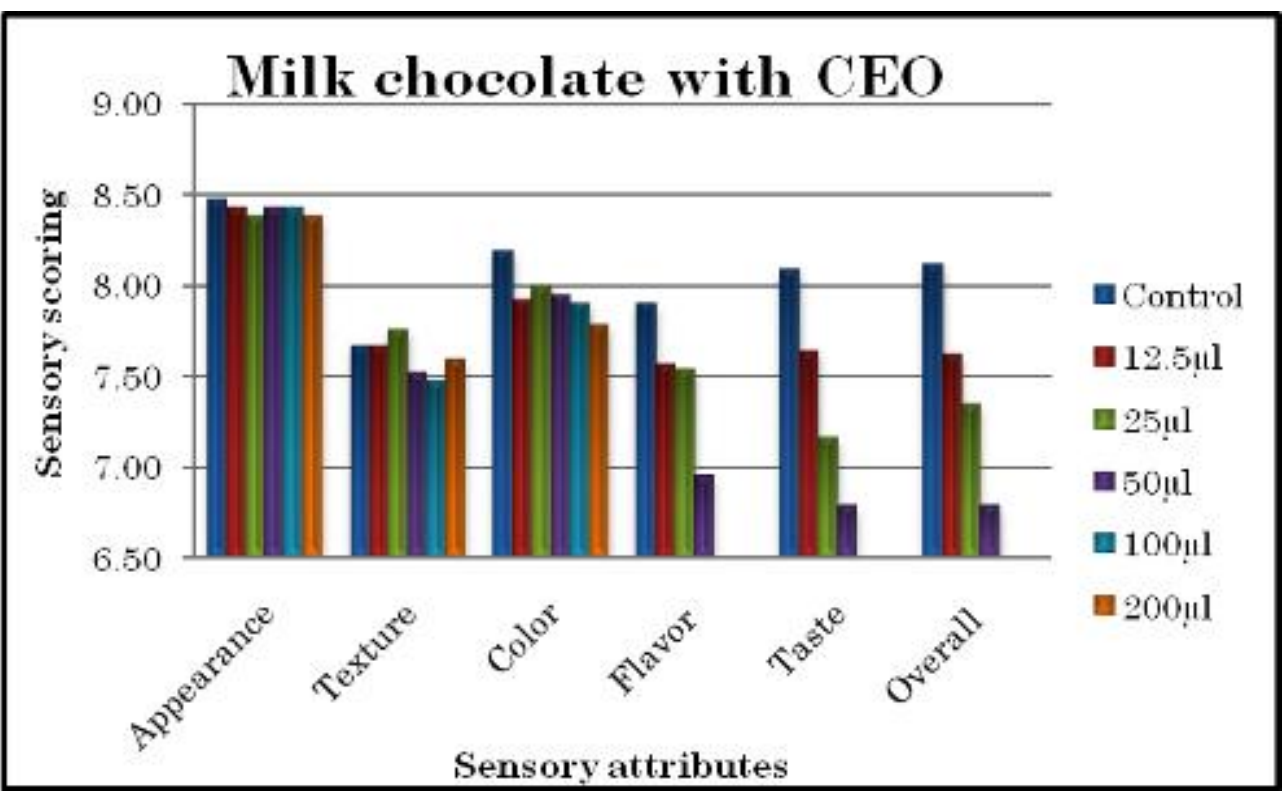


Fig.5 Effect on sensory scores of fennel essential oil (FEO) incorporation in protein bars coated with dark chocolate

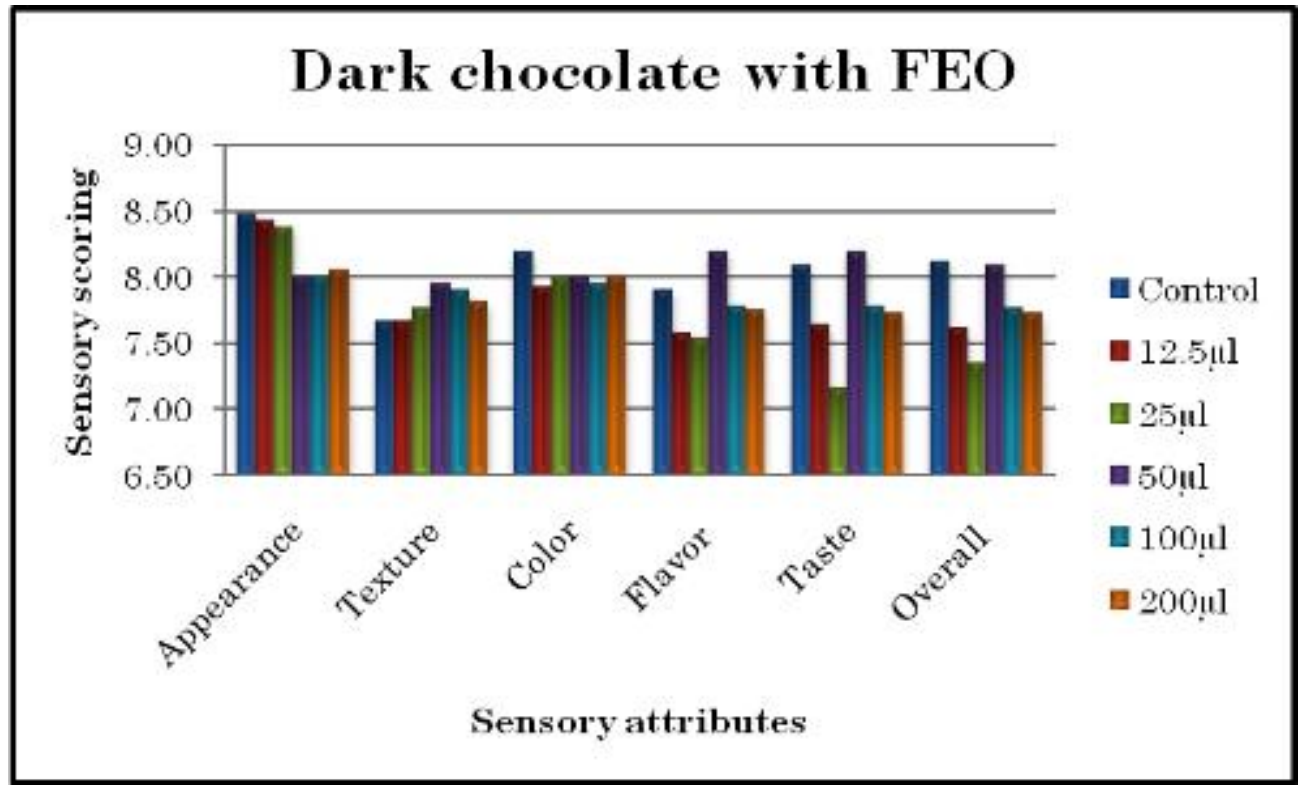

Fig.6 Effect on sensory scores of fennel essential oil (FEO) incorporation in protein bars coated with milk chocolate

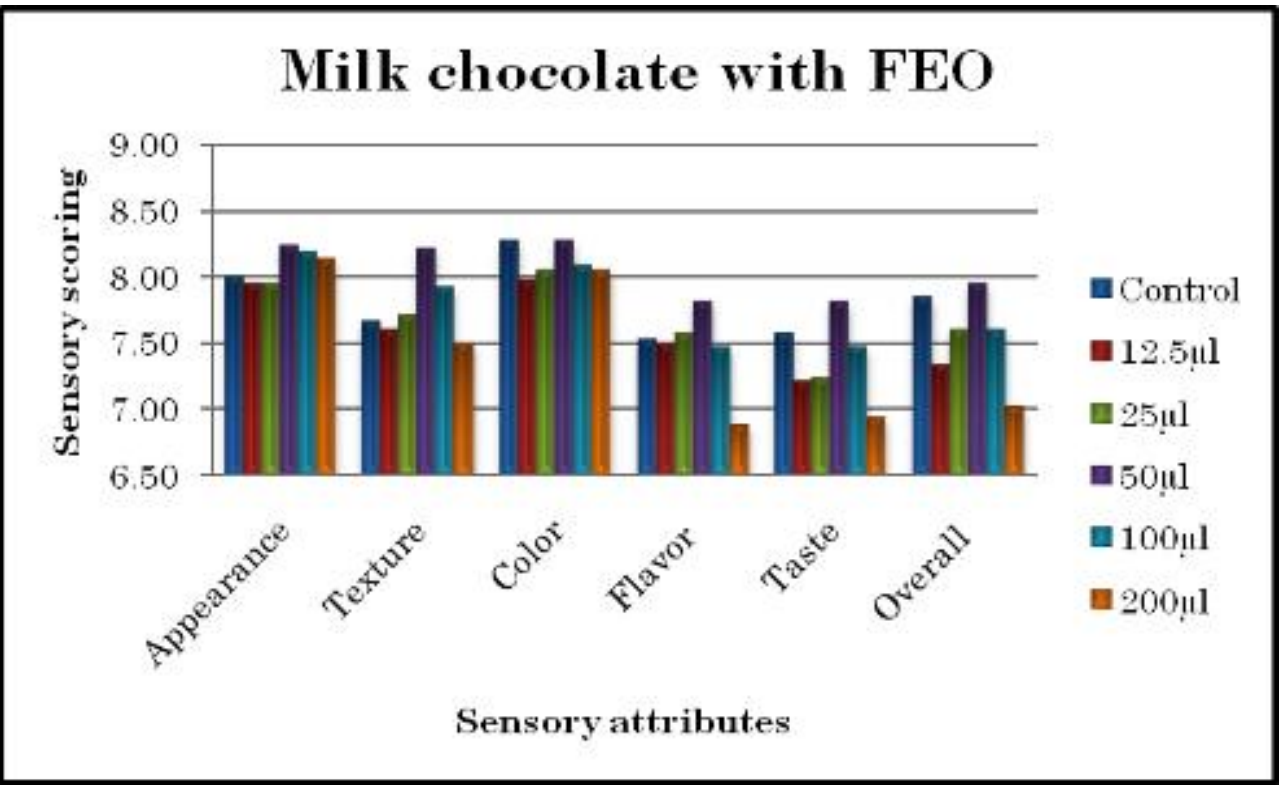


Plate.1 Protein bar samples

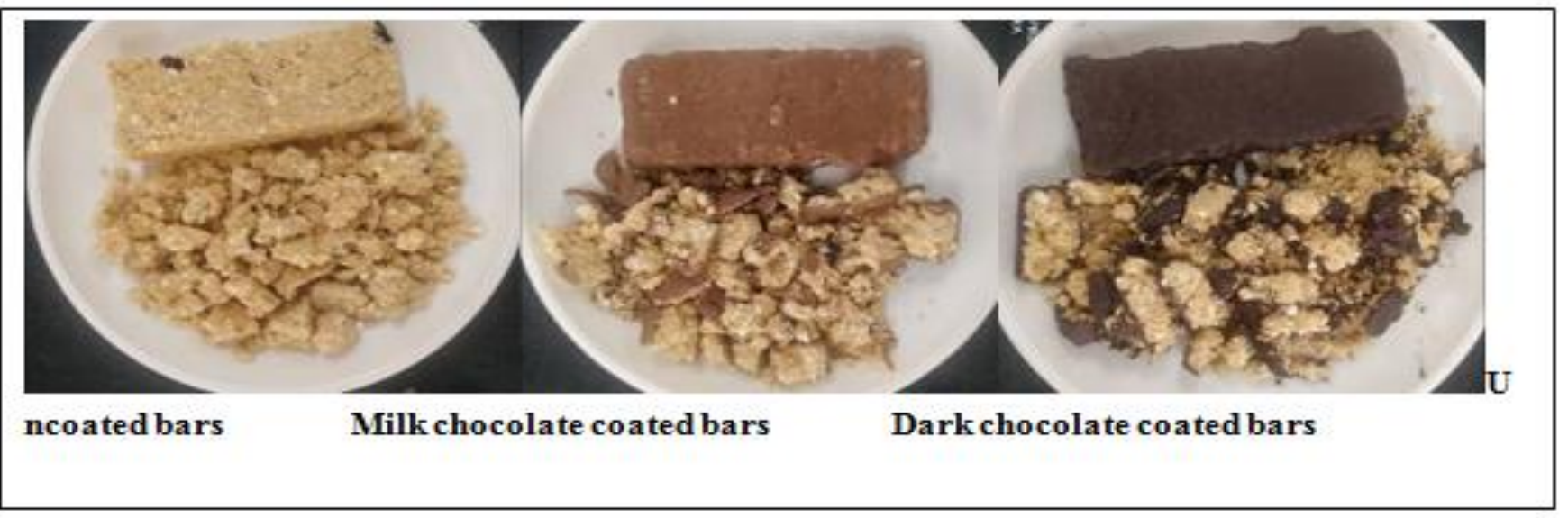

Maghami (2019) reported that the chitosan nanoparticles (CNPs) loaded with fennel essential oils enhanced the shelf life for $H$. huso fillets up to 18 days in the fridge with significant reduction in the peroxide value, total volatile nitrogen, and thiobarbituric acid value compared with the control samples and showed high acceptability in all sensorial attribute through the storage. Further lower number of mesophilic, psychotropic, pseudomonas, and lactic acid bacteria was detected in coated fillets compared with control packaging.

\section{Fennel essential oil incorporation in milk chocolate}

The results of effect of fennel essential oil incorporation in milk chocolate coating of protein bars on the sensory acceptability are given in Figure 6.

The mean sensory scores for all the sensory parameters for control and fennel essential oil incorporated protein bars at different concentrations were non-significant except for overall acceptability. The mean sensory values for overall acceptability showed highest scores at 25 and $50 \mu 1$ of essential oil incorporation and marginal taste scores were obtained at
$12.5 \mu 1$ concentrations which are also on par with the control protein bar samples. Least scores were obtained at higher essential oil incorporation $(100 \mu \mathrm{l}$ and $200 \mu \mathrm{l})$, for overall acceptability parameter.

From the sensory analysis results it was revealed that the fennel essential oil in milk chocolate coating of protein bar samples was liked by the panellists up to $50 \mu \mathrm{l}$ concentration and the sensory scores. Effect of fennel (Foeniculum vulgare Mill) essential oil on the quality parameters and shelf-life prediction of yoghurt revealed that the addition of $5 \mu \mathrm{L}$ of fennel essential oil had the highest overall liking whereas the highest concentration of essential oil $(7.5 \mu \mathrm{L})$ had significant effect on the aroma of yoghurt, and obtained lower scores Ben et al., (2020). The decrease in the panellists acceptance with increasing concentration of fennel essential oil might be due to sharp bitter taste, biting characteristic and warmth impression caused by the essential oils (Inna et al., 2010).

The chocolate coated protein bars were more liked by the panellists when compared to noncoated protein bars. Among the coating material milk chocolate was more acceptable compared to dark chocolate as revealed by 
sensory evaluation. However, all were found to be acceptable. The sensory scores of protein bars incorporated with essential oils in chocolate coating was improved significantly, particularly in case of milk chocolate+ fennel essential oil and dark chocolate+ cinnamon essential oil protein bar samples. Hence in the present study both the coating material and essential oil incorporation has showed significant role in sensory qualities of the developed protein bars

\section{References}

Abd-Elsalam, K. A. and Khokhlov, A. R., 2015. Eugenol oil nanoemulsion: antifungal activity against Fusarium oxysporum f. sp. vasinfectum and phytotoxicity on cottonseeds. Applied Nanoscience, 5(2), pp.255-265.

Adinew, B. Int. J. Herb. Medicine, 2014, 1, 22-31.

Aparecida Damasceno, K., Alvarenga Gonçalves, C. A., Dos Santos Pereira, G., Lacerda Costa, L., Bastianello Campagnol, P.C., Leal De Almeida, P. and Arantes-Pereira, L., 2016. Development of cereal bars containing pineapple peel flour (Ananas comosus L. Merril). Journal of Food Quality, 39(5), pp.417-424.

Artaza-Artabe, I., Sáez-López, P., SánchezHernández, N., Fernández-Gutierrez, N. and Malafarina, V., 2016. The relationship between nutrition and frailty: Effects of protein intake, nutritional supplementation, vitamin D and exercise on muscle metabolism in the elderly. A systematic review. Maturitas, 93, pp.89-99.

Ben Abdesslem, S., Ben Moussa, O., Boulares, M., Elbaz, M., Chouaibi, M., Ayachi, S. and Hassouna, M., 2020. Evaluation of the effect of fennel (Foeniculum vulgare Mill) essential oil addition on the quality parameters and shelf-life prediction of yoghurt. International Journal of Dairy Technology, 73(2), pp.403-410.

Bhaludra, N. H., 2019. Protein Bars and Packaging: A Sequential Explanatory Research to investigate the impact of packaging on consumer perceptions and intention to purchase in Ireland (Doctoral dissertation, Dublin, National College of Ireland).

Costa, D. C., Costa, H. S., Albuquerque, T. G., Ramos, F., Castilho, M. C. and Sanches-Silva, A., 2015. Advances in phenolic compounds analysis of aromatic plants and their potential applications. Trends in Food Science \& Technology, 45(2), pp.336-354.

Dwijatmoko, M. I., Praseptiangga, D. and Muhammad, D. R. A., 2016. Effect of cinnamon essential oils addition in the sensory attributes of dark chocolate. Nusantara Bioscience, 8(2), pp.301305.

Fernández-López, J. and Viuda-Martos, M., 2018. Application of essential oils in food systems. MDPI.

FSSAI, 2019. Notice for operationalization of Food Safety and Standards (Advertising and Claims), https://archive.fssai.gov.in/home/fsslegislation/notifications/ gazettenotification.html.

Glicerina, V., Balestra, F., Dalla Rosa, M. and Romani, S., 2016. Microstructural and rheological characteristics of dark, milk and white chocolate: A comparative study. Journal of Food Engineering, 169, pp.165-171.

Ilmi, A., Praseptiangga, D. and Muhammad, D. R. A., 2017, April. Sensory attributes and preliminary characterization of milk chocolate bar enriched with cinnamon essential oil. In IOP conference series: Materials science and engineering (Vol. 193, No. 1, p. 012031). IOP Publishing. 
Inna, M., Atmania, N. and Prismasari, S., 2010. Potential use of Cinnamomum burmanii essential oil-based chewing gum as oral antibiofilm agent. Journal of dentistry Indonesia, 17(3), pp.80-86.

Ju, J., Xu, X., Xie, Y., Guo, Y., Cheng, Y., Qian, H. and Yao, W., 2018. Inhibitory effects of cinnamon and clove essential oils on mold growth on baked foods. Food chemistry, 240, pp.850-855.

Kimberlee, J.B., 2007. Us Whey ingredients in nutrition bars and gels. Arlington: USDEC.

Lu, N. and Zhou, P., 2019. Whey proteinbased nutrition bars. In Whey Proteins (pp. 495-517). Academic Press.

Maghami, M., Motalebi, A. A. and Anvar, S. A. A., 2019. Influence of chitosan nanoparticles and fennel essential oils (Foeniculum vulgare) on the shelf life of Huso huso fish fillets during the storage. Food science \& nutrition, 7(9), pp.3030-3041.

Małecki, J., Tomasevic, I., Djekic, I. and
Sołowiej, B. G., 2020. The Effect of Protein Source on the Physicochemical, Nutritional Properties and Microstructure of High-Protein Bars Intended for Physically Active People. Foods, 9(10), p.1467.

Padmashree, A., Sharma, G. K. and Govindaraj, T., 2013. Development and evaluation of shelf stability of flaxoat nutty bar in different packaging materials. Food Nutr Sci 4: 538-46.

Padmashree, A., Sharma, G.K., Srihari, K.A. and Bawa, A.S., 2012. Development of shelf stable protein rich composite cereal bar. Journal of food science and technology, 49(3), pp.335-341.

Pallavi, B. V., Chetana, R. and Reddy, S. Y., 2014. Processing, physico-chemical, sensory and nutritional evaluation of protein, mineral and vitamin enriched peanut chikki-an Indian traditional sweet. Journal of food science and technology, 51(1), pp.158-162.

\section{How to cite this article:}

Aishwarya Ayatti, Neena Joshi, K. V. Jamuna and Suresha, K. B. 2021. Effect of Chocolate Coating and Essential Oil Incorporation on the Sensory Acceptability of Protein Bars. Int.J.Curr.Microbiol.App.Sci. 10(07): 229-240. doi: https://doi.org/10.20546/ijcmas.2021.1007.025 